ORIGINAL

\title{
Trophic ecology of Saccodon dariensis (Pisces: Parodontidae) in Guatapé River tributaries, Magdalena River Basin, Colombia
}

\section{Ecología trófica de Saccodon dariensis (Pisces: Parodontidae) en afluentes del río Guatapé, Cuenca río Magdalena, Colombia}

Ana Restrepo-Gómez, Zoot, Néstor Mancera-Rodríguez,* Ph.D.

Universidad Nacional de Colombia, Departamento de Ciencias Forestales. Posgrado en Bosques y Conservación Ambiental. Medellín, Colombia. Correspondencia: njmancer@gmail.com

Received: April 2013; Accepted: September 2013.

\begin{abstract}
Objective. To study the trophic ecology of Saccodon dariensis in the Peñoles and El Cardal streams, Guatape River mid-basin, Magdalena River Basin, Colombia. Materials and methods. To compare differences in size between individuals from the two streams in terms of hydrologic periods, oral polymorphisms or sexes, an analysis of variance was conducted (ANOVA). Volume percentages, frequency of occurrence and the food importance index (FII) were determined; a principal component analysis (PCA) and an ANOVA was carried out to determine the diet differences between streams, climatic periods, oral polymorphism, sexes and developmental states, as well as a Mann-Whitney pairwise comparison test for each food category. Results. A significant difference was found in size between individuals of the two streams with different oral polymorphism. Algae are the most important food item (FII: $91.9 \%$ ), followed by Trichoptera and insect remains (FII: $4.3 \%$ ), and vegetal material (FII : $1.8 \%$ ). The PCA did not indicate significant differences in diet between streams, climatic periods, oral polymorphisms, sexes or developmental states, but the ANOVA and Mann-Whitney pairwise comparison test indicated differences in oral morphotype, where individuals with a straight mouth consumed more vegetal material. We also observed different proportions in consumption of different algae genera, and increased consumption of insects in ontogeny, this being higher in individuals with a straight mouth. Conclusions. The species is algaevorous. The oral morphotypes of $S$. dariensis may be related to a trophic polymorphism that confers different trophic habits and differential access to the items that constitute their diet.
\end{abstract}

Key words: Algae, conservation, fish feeding, polymorphism (Source: AIMS, CAB). 


\section{RESUMEN}

Objetivo. Estudiar la ecología trófica de Saccodon dariensis en las quebradas Peñoles y El Cardal, parte media del río Guatape, cuenca del rio Magdalena, Colombia. Materiales y métodos. Para contrastar diferencias entre individuos de las dos quebradas en cuanto a períodos hidrológicos, polimorfismos bucales y sexos se realizó un análisis de varianza (ANOVA). Se determinó los porcentajes de volumen, frecuencia de ocurrencia e índice de importancia alimentaria (IIA); se realizó un análisis de componentes principales (ACP) y un ANOVA para determinar diferencias de dieta entre quebradas, períodos climáticos, polimorfismos bucales, sexos, estados de desarrollo, y una prueba de comparación por pares de Mann-Whitney para cada categoría de alimento. Resultados. Se encontró diferencia significativa en la talla entre individuos de las dos quebradas con diferente morfotipo bucal. Las algas es el item de alimento más importante (IIA: 91.9\%), seguido por Trichoptera y restos de insectos con (IIA: $4.3 \%$ ) y material vegetal (IIA: $1.8 \%$ ). El ACP no indicó diferencias en la alimentación entre quebradas, períodos climáticos, polimorfismo bucal, sexos o estados de desarrollo, pero la ANOVA y la prueba de Mann-Whitney indicaron diferencias por morfotipo bucal, donde individuos de boca recta consumen más material vegetal. Se observó en proporciones diferentes el consumo de diferentes géneros de algas, y aumento de consumo de insectos en ontogenia, siendo más alto para individuos de boca recta. Conclusiones. La especie es alguivora. Los morfotipos bucales en S. dariensis pueden estar relacionados con un polimorfismo trófico que le confiere diferentes hábitos tróficos y acceso diferencial a los ítems que constituyen su dieta.

Palabras clave: Algas, alimentación de peces, conservación, polimorfismo (Fuente: AIMS, CAB).

\section{INTRODUCCIÓN}

Colombia posee la diversidad más alta en especies de peces de montaña dentro de la región Andina, con aproximadamente 220 especies, de las cuales alrededor del $37 \%$ son endémicas (1). Sin embargo, esta diversidad es vulnerable a los cambios ambientales actuales generados por el hombre, como la alteración de ecosistemas por fragmentación y deforestación, la pérdida y contaminación de cuerpos de agua, la introducción de especies exóticas, la alteración en las dinámicas de regulación hídrica con el desarrollo de hidroeléctricas y alta presión sobre recursos hidrobiológicos (2), que actúan al disminuir las poblaciones naturales; colocando en riesgo de extinción a muchas especies de peces. A pesar de esta problemática, aún es poco el conocimiento de muchos aspectos de la ecología trófica de peces andinos, y conocerlos ayudaría a establecer recomendaciones para su protección, conservación y manejo.

La familia Parodontidae está compuesta por los géneros Parodon Valenciennes 1849 y Saccodon Kner 1863 (3), los que tienen una distribución geográfica amplia en el centro y sur de América, desde el Canal de Panamá hasta la cuenca del rio de la Plata en Argentina, excepto en las cuencas del sur del Estado de Bahía en Brasil en la Costa Atlántica, la Patagonia, y el canal del río Amazonas (4). En su mayoría no exceden los $20 \mathrm{~cm}$ de longitud, no son importantes comercialmente (4-5), y consumen preferencialmente algas e insectos acuáticos $(4,6-$ 10), aunque Parodon cf. gestri, ha sido ubicado dentro del grupo de los detritívoros (11).

\section{INTRODUCTION}

Colombia has the highest diversity in mountain fish species within the Andean region, with approximately 220 species, of which around $37 \%$ are endemic (1). However, this diversity is vulnerable to current environmental changes generated by man, such as the alteration of ecosystems by fragmentation and deforestation, loss and pollution of water bodies, introduction of exotic species, alteration of water regulation dynamics with the development of hydroelectric plants and high pressure on hydrobiological resources (2), that diminish natural populations; placing many fish species in the brink of extinction. Despite this problem, still there is little knowledge of many aspects of the trophic ecology of Andean fish, and knowing them would help establishing recommendations for their protection, conservation and handling.

The family Parodontidae consists of the genera Parodon Valenciennes 1849 and Saccodon Kner 1863 (3), which have a wide geographical distribution in Central and South America, from the Panama Canal to the basin of Rio de la Plata in Argentina, except in the basins to the south of the State of Bahia in Brazil in the Atlantic Coast, Patagonia, and the channel of the Amazon River (4). They mostly do not exceed $20 \mathrm{~cm}$ in length, have no commercial importance (4-5), and preferentially consume algae and aquatic insects (4, 6-10), although Parodon cf. gestri has been placed within the detrivores group (11). 
Saccodon dariensis (Meek \& Hildebrand, 1913) se distribuye en Centro y Suramérica, en aguas continentales al oriente del canal de Panamá y en Colombia en las cuencas de los ríos Atrato y Magdalena $(4,12)$, en particular en los departamentos de Cauca y Valle del Cauca (13-14), Tolima (15) y Antioquia (1,16-17). La especie se encuentra asociada a sitios de corrientes rápidas, bajas pendientes y sustratos rocosos cubiertos de perifiton.

Diferencias morfológicas intraespecíficas han sido reportadas en varias especies de fauna, las cuales se han descrito como "polimorfismos tróficos", estando relacionadas con las estructuras encargadas de la alimentación y que pueden conferir ventajas en el uso del hábitat y recursos particulares (18). Roberts (5) ha señalado cinco polimorfismos bucales y dentales en Saccodon dariensis en afluentes de los ríos Sinú, Magdalena, alto Cauca y Atrato, y menciona la relación de éstos y posibles diferencias en la explotación de recursos alimenticios. Para la cuenca del río Guatapé se ha descrito la co-existencia de dos de éstos polimorfismos bucales. La especie presenta dientes altamente especializados para raspar algas adheridas al sustrato rocoso en los ecosistemas acuáticos. Algunos morfotipos tienen dientes premaxilares en línea recta y otros poseen $6 \mathrm{u}$ 8 dientes escalonados en forma de medialuna; consume insectos acuáticos de los órdenes Diptera, Trichoptera, Ephemeroptera y Plecoptera que se adhieren a la superficie de las rocas (10).

El objetivo de este trabajo fue estudiar la ecología trófica del mazorco, Saccodon dariensis, en las quebradas Peñoles y El Cardal, parte media del río Guatapé, cuenca del río Magdalena, y determinar si existen diferencias significativas en la dieta entre sexos, estados de desarrollo, quebradas y períodos climáticos, y si el polimorfismo bucal (boca recta vs boca en media luna) está relacionado con un polimorfismo trófico. Esta información es importante para la formulación de programas de conservación y manejo de la especie, que está incluida en el Libro Rojo de Peces Dulceacuícolas de Colombia en la categoría de Preocupación Menor (10).

\section{MATERIALES Y MÉTODOS}

Área de estudio. El trabajo se realizó en las quebradas Peñoles $\left(6^{\circ} 16^{\prime} 27.2^{\prime \prime} N\right.$, $75^{\circ} 05^{\prime} 23.7^{\prime \prime} \mathrm{O}$; $1201 \mathrm{msnm}$ ) y El Cardal (6016'46.6" N, 74055'24.6" O; $898 \mathrm{msnm})$, afluentes del río Guatapé, cuenca del río Magdalena, en los municipios de San Rafael y San Carlos en la región del oriente de Antioquia, Colombia (Figura 1).
Saccodon dariensis (Meek Hildebrand, 1913) is distributed in Central and South America, in inland waters to the east of the Panama Canal and in Colombia in the basins of the rivers Atrato and Magdalena $(4,12)$, in particular in the departments of Cauca and Valle del Cauca (13-14), Tolima (15) and Antioquia $(1,16-17)$. The species is associated with sites that have fast-flowing currents, low slopes and rocky substrates covered with periphyton.

Intraspecific morphological differences have been reported in several wildlife species, which have been described as "trophic polymorphism," being related to the structures responsible for food and which can confer advantages in the use of the habitat and specific resources (18). Roberts (5) has noted five oral and dental polymorphisms for Saccodon dariensis in tributaries of the rivers Sinu, Magdalena, upper Cauca and Atrato, and mentions the relationship of these and the possible differences in the exploitation of food resources. In the Guatape River basin, the coexistence of two of these oral polymorphisms has been described. The species has highly specialized teeth to scrape algae attached to the bedrock in aquatic ecosystems. Some morphotypes have premaxillary teeth in a straight line and others have 6 or 8 crescentshaped teeth; consumes aquatic insects from the Diptera, Trichoptera, Ephemeroptera, and Plecoptera order that adhere to the surface of the rocks (10).

The objective of this study was to study the trophic ecology of the mazorco, Saccodon dariensis, in the Peñoles and El Cardal streams, Guatape River mid-basin, Magdalena River basin, and to determine if there are significant differences in diet between sexes, developmental states, streams and climatic periods, and if oral polymorphism (straight mouth vs. crescent-shaped mouth) is related to a trophic polymorphism. This information is important for the formulation of programmes for the conservation and handling of the species, which is included in the Red Book of Freshwater Fishes of Colombia in the category of Minor Concern (10).

\section{MATERIALS AND METHODS}

Study area. The study was carried out in the

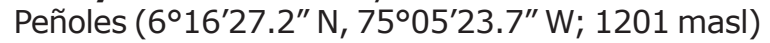
and El Cardal streams (6¹6'46.6" N, 74 $55^{\prime} 24.6^{\prime \prime}$ W; 898 masl), tributaries of the Guatape River, Magdalena River basin, in the municipalities of San Rafael and San Carlos in the region east of Antioquia, Colombia (Figure 1). 

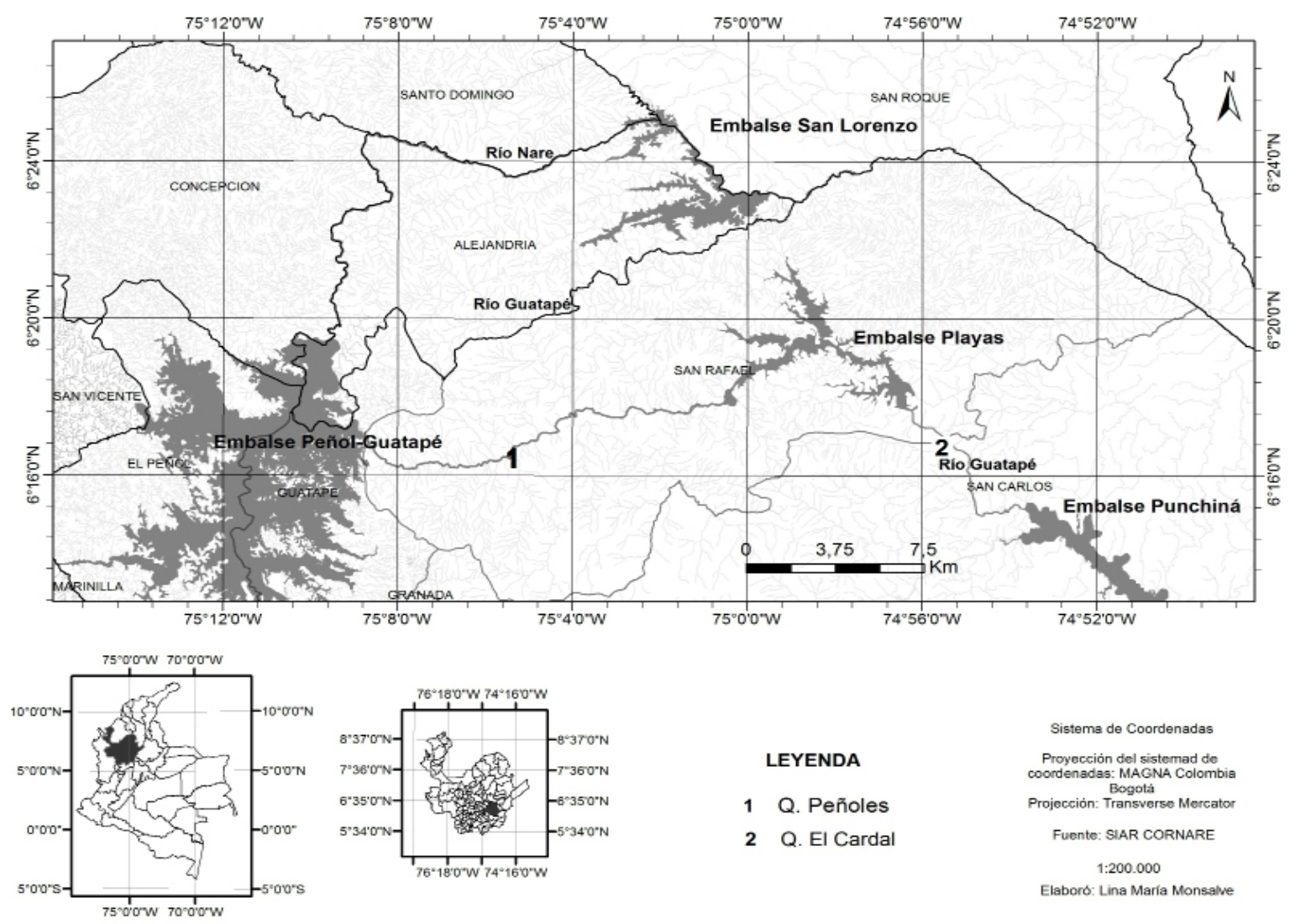

Figure 1. Location of the Peñoles and El Cardal streams in the Guatape river mid-basin, East of Antioquia, Colombia.

La zona presenta ecosistemas característicos de zonobioma húmedo tropical del valle del río Magdalena, con una temperatura promedio de $23-28^{\circ} \mathrm{C}(19)$, y un patrón de distribución de la precipitación bimodal con picos de lluvias en mayo y octubre, y un promedio anual de $4368 \mathrm{~mm}$ (Estación climatológica embalse de playas). El territorio es montañoso, con topografía ondulada, y las quebradas se caracterizan por ser torrenciales, de aguas muy claras y sin planicie aluvial.

Caracterización del hábitat. Las siguientes variables fisicoquímicas fueron tomadas in situ: oxígeno disuelto $(\mathrm{mg} / \mathrm{l})$, saturación de oxígeno $(\%)$, temperatura superficial del agua $\left({ }^{\circ} \mathrm{C}\right)$ con medidor HANNA (HI9828/4-01) y $\mathrm{pH}$, conductividad $(\mu \mathrm{S} / \mathrm{cm})$ y sólidos totales disueltos (STD) con medidor HANNA (9811-5). Ancho y profundidad fueron medidos con flexómetro, y una vara graduada en centímetros y el tipo de sustrato se clasificó de acuerdo con la escala propuesta por Wentworth (20).

Obtención de las muestras. Se realizaron seis muestreos de campo que incluyeron períodos de lluvia (octubre y noviembre de 2007, mayo de 2008), seco (enero y marzo de 2010) y transición
The area shows tropical moist biome ecosystems characteristic of the Magdalena River valley, with an average temperature of $23-28^{\circ} \mathrm{C}(19)$, and a bimodal precipitation distribution pattern with rainfall peaks in May and October, and an annual average of $4368 \mathrm{~mm}$ (Embalse de las Playas weather station). The territory is mountainous, with an undulating topography, and the streams are characterized by being torrential, with very clear water and no alluvial plains.

Habitat characterization. The following physicochemical variables were taken in situ: dissolved oxygen ( $\mathrm{mg} / \mathrm{l})$, oxygen saturation (\%), surface water temperature $\left({ }^{\circ} \mathrm{C}\right)$ with HANNA meter (HI9828/4-01) and $\mathrm{pH}$, conductivity $(\mu \mathrm{S} / \mathrm{cm})$ and total dissolved solids (TDS) with HANNA meter (9811-5). The width and depth were measured with a measuring tape, and a rod in centimeters and the type of substrate was classified according to the scale proposed by Wentworth (20).

Obtaining of samples. Six field samplings were carried out which included periods of rain (October and November 2007, May 2008), draught (January to March 2010) and dry to rain transition (March 2008). Specimens were captured with 30 
de seca a lluvia (marzo de 2008). Se efectuaron capturas de individuos con 30 lances de atarraya de $1 \mathrm{~cm}$ ojo de malla por estación y por medio de equipo de electropesca SAMUS 725MP, el cual se usó con descargas en un tramo lineal de $100 \mathrm{~m}$ por estación, haciendo barridos en contra de la corriente, y de ribera a ribera, que incluyera todos los biotopos posibles. Una vez capturados, los peces se etiquetaron con fecha, lugar de captura y arte de pesca, se depositaron en bolsas plásticas y se fijaron en formol al 10\%. La identificación de contenido estomacal se realizó en el laboratorio de Ecología y Conservación de Fauna Silvestre de la Universidad Nacional de Colombia, Sede Medellín. Ejemplares de S. dariensis se preservaron en alcohol al $70 \%$ y están depositados en los Laboratorios de Ictiología de la Universidad del Quindío, Armenia, Colombia (IUQ) y de Limnología y Recursos Hídricos de la Universidad Católica de Oriente, Ríonegro, Antioquia, Colombia (UCO).

Análisis de contenido estomacal. Los ejemplares recolectados fueron lavados con agua para eliminar el exceso de formaldehido y luego pasados a alcohol al $70 \%$. En total se examinaron 117 estómagos de individuos de $S$. dariensis, de los cuales 53 fueron capturados en la quebrada Peñoles y 64 en la quebrada El Cardal. De estos 70 eran hembras y 47 machos, y 53 presentaban boca recta y 65 boca en forma de media luna (Tabla 1).

A los ejemplares se les midió la longitud estándar (LE) en $\mathrm{mm}$ con un calibrador digital (Mitutoyo Serie 500) hasta centésimas de milímetro y el peso total $(\mathrm{g})$ y eviscerado $(\mathrm{g})$, con una balanza analítica (Ohaus Scout-Pro SP202, New Jersey, USA) hasta dos décimas de precisión $(0.01 \mathrm{~g})$ y se les practicó una disección uroventral para la extracción de la gónada para la identificación del sexo y del tracto digestivo al cual se le midió el largo y ancho del estómago, la longitud del intestino y el número de ciegos pilóricos. Para contrastar diferencias de tamaño entre quebradas, períodos hidrológicos, polimorfismos bucales y sexos se realizó un análisis de varianza sets of cast nets with chain links of $1 \mathrm{~cm}$ by station and with SAMUS 725MP electrofishing equipment, which was used on a linear stretch of $100 \mathrm{~m}$ per station, sweeping against the current, and from bank to bank, which included all possible biotopes. Once captured, fish were tagged with date, place of catch and fishing gear, they were placed in plastic bags and left in formalin at $10 \%$. The identification of stomach contents was carried out in the Wildlife Ecology and Conservation Laboratory of Universidad Nacional de Colombia, Medellin. The specimens of $S$. dariensis were preserved in alcohol at $70 \%$ and are stored in the Ichthyology Laboratory of Universidad del Quindio, Armenia, Colombia (IUQ) and in the Limnology and Water Resources Laboratory of Universidad Catolica de Oriente, Rionegro, Antioquia, Colombia (UCO).

Analysis of stomach contents. The specimens collected were washed with water to remove the excess of formaldehyde and then were put in alcohol at $70 \%$. In total 117 stomachs of individuals of $S$. dariensis were examined, of which 53 were captured in the Peñoles stream and 64 in the El Cardal stream. Of these 70 were females and 47 males, and 53 had a straight mouth and 65 a crescent-shaped mouth (Table 1).

The standard length $(\mathrm{SL})$ in $\mathrm{mm}$ of the specimens was measured with a digital gauge (Mitutoyo 500 Series) up to hundredths of a $\mathrm{mm}$ and the total $(\mathrm{g})$ and eviscerated weight $(\mathrm{g})$ with an analytical scale (Ohaus Scout Pro SP202, New Jersey, USA) up to two tenths of precision $(0.01 \mathrm{~g})$ and underwent a ventral dissection for extracting gonads for gender identification and the digestive tract, with which the length and width of the stomach, the length of the intestine and the number of pyloric caeca was measured. An analysis of variance (ANOVA) was performed to contrast the differences in size between streams, hydrological periods, oral polymorphisms and sexes. A linear correlation was made between the standard length $(S L)$ and the

Table 1. Number of individuals of Saccodon dariensis studied by sex, stream, climatic period and oral morphotype in the Guatape River mid-basin, East of Antioquia, Colombia.

\begin{tabular}{|c|c|c|c|c|c|c|c|c|}
\hline \multirow{3}{*}{ Stream } & \multirow{3}{*}{$\begin{array}{c}\text { Period } \\
\text { Sex }\end{array}$} & \multicolumn{6}{|c|}{ Mouth shape } & \multirow{3}{*}{ Total } \\
\hline & & \multicolumn{3}{|c|}{ Straight mouth } & \multicolumn{3}{|c|}{ Crescent-shaped mouth } & \\
\hline & & M & $\mathbf{F}$ & Total & M & $\mathbf{F}$ & Total & \\
\hline \multirow{3}{*}{ Peñoles } & Rain & 5 & 6 & 11 & 9 & 2 & 11 & 22 \\
\hline & Transition & 2 & 1 & 3 & 3 & 6 & 9 & 12 \\
\hline & Dry & 6 & 3 & 9 & 4 & 6 & 10 & 19 \\
\hline \multirow[t]{2}{*}{ Total Peñoles } & & 13 & 10 & 23 & 16 & 14 & 30 & 53 \\
\hline & Rain & 7 & 3 & 10 & 7 & 3 & 10 & 20 \\
\hline \multirow[t]{2}{*}{ El Cardal } & Transition & 4 & 6 & 10 & 8 & 2 & 10 & 20 \\
\hline & Dry & 5 & 5 & 10 & 10 & 4 & 14 & 24 \\
\hline Total El Cardal & & 16 & 14 & 30 & 25 & 9 & 34 & 64 \\
\hline Total & & 29 & 24 & 53 & 41 & 23 & 64 & 117 \\
\hline
\end{tabular}


(ANOVA). Se realizó una correlación lineal entre la longitud estándar (LE) vs la longitud del intestino, la longitud estándar (LE) vs la longitud del estómago, la longitud estándar (LE) vs el ancho del estómago, y una correlación potencial entre el peso total del pez vs su longitud estándar.

Para el análisis de la dieta, se realizó una separación de las categorías de alimento fácilmente reconocibles con estereoscopio EZ4 (Leica Microsystems) y el resto de contenido estomacal y del intestino se diluyó en $2 \mathrm{ml}$ de agua destilada, se tomaron gotas (submuestras de volumen conocido) y se observaron en microscopio (Leica Microsystems). Se realizó la separación e identificación de los elementos alimenticios de manera cualitativa y cuantitativa de acuerdo con los métodos volumétrico y de frecuencia de ocurrencia $(21,22)$, y se calculó el índice de importancia alimentaria (IIA) según Kawakami y Vazzoler (23) IIA $=F i * V I / \Sigma(F i * V i)$, donde IIA = índice de importancia alimentaria, $\mathrm{Fi}=$ frecuencia de ocurrencia $(\%)$ de cada categoría y $\mathrm{Vi}=$ volumen (\%) de cada categoría. La determinación taxonómica de los diferentes ítems se basó en claves taxonómicas (24-28).

Análisis de la información. Se realizó un análisis de componentes principales para establecer diferencias significativas en la dieta entre quebradas (Peñoles y El Cardal), períodos climáticos (lluvia, transición y seco), polimorfismo bucal (boca recta o en media luna), y estado de desarrollo (juveniles y adultos), y se realizó una prueba de la comparación por pares de Mann-Whitney para determinar si existen diferencias en el consumo de cada categoría de alimento por tipo de boca y estado de desarrollo. Para los estados de desarrollo se separaron en dos categorías de tallas, se consideraron juveniles a los individuos con una longitud inferior a la talla media de madurez sexual correspondiente, a $88.8 \mathrm{~mm}$ de largo estándar para las hembras y $109.3 \mathrm{~mm}$ para los machos, según fue establecido por UrregoBallestas et al (17) y adultos a los individuos con una longitud igual o mayor a estos valores.

\section{RESULTADOS}

Características del hábitat. La quebrada Peñoles se caracteriza por presentar sustrato pedregoso o de guijarros, con pendiente inclinada cercana a un ángulo de unos $25^{\circ}$, y aguas arriba del punto de muestreo se observó la presencia de rocas de gran tamaño. Durante la época seca sus aguas son cristalinas y en época de lluvias turbias y con corriente fuertes. En sus riberas se observó bosque nativo y algunos potreros para ganadería. Cincuenta metros antes de la desembocadura al río Guatapé se observa una vía de concreto con corazón de acero que cruza la quebrada para el length of the intestine, the standard length $(\mathrm{SL})$ and the length of the stomach, the standard length $(\mathrm{SL})$ and the width of the stomach, and a potential correlation between the total weight of the fish vs. its standard length.

For the analysis of the diet, a separation of easily recognizable food categories was made with a EZ4 stereoscope (Leica Microsystems) and the rest of the stomach and intestine contents were diluted in $2 \mathrm{ml}$ of distilled water, drops (known volume subsamples) were taken and observed under a microscope (Leica Microsystems). The separation and identification of nutritional elements was carried out in a qualitative and quantitative basis according to the volumetric and frequency of occurrence methods $(21,22)$, and the food importance index (FII) was calculated according to Kawakami and Vazzoler (23) $\mathrm{FII}=\mathrm{Fi} * \mathrm{VI} / \Sigma(\mathrm{Fi} * \mathrm{Vi})$, where $\mathrm{FII}=$ food importance index, $\mathrm{Fi}=$ frequency of occurrence (5) of each category and $\mathrm{Vi}=$ volume (\%) of each category. The taxonomic determination of the different items was based on taxonomic cues (24-28).

Analysis of information. A principal components analysis was performed to establish significant differences in diet between streams (Peñoles and El Cardal), climatic periods (rain, transition and drought), oral polymorphism (straight mouth or crescent-shaped mouth), and developmental state (youth and adults), and a Mann-Whitney pairwise comparison test was conducted to determine if there are differences in the consumption of each food category by mouth type and developmental state. For the developmental states the fish was separated into two size categories, those considered young corresponded to individuals with a length less than the mean size at sexual maturity of 88.8 $\mathrm{mm}$ standard length for females and $109.3 \mathrm{~mm}$ for males, as established by Urrego-Ballestas et al (17) and adults as those individuals with a length equal to or greater than these values.

\section{RESULTS}

Habitat characteristics. The Peñoles stream is characterized by having a rocky or pebbly substrate, with an incline with an angle of approximately $25^{\circ}$, and the presence of large rocks was observed upstream the sampling site. During the dry season, its waters are crystal clear and in the rainy season they are turbid with a strong current. A native forest and some pasture for livestock were observed on its banks. Fifty meters before the mouth of the Guatape river there is a concrete-steel road that crosses the stream for vehicle access to a farm, becoming 
acceso de vehículos a una finca, constituyéndose en una barrera principalmente en época seca, cuando baja el caudal de la quebrada. Presentó una profundidad media entre 0.40-0.60 m, aunque con algunas pozas de mayor profundidad. El ancho promedio fue de $16.5 \mathrm{~m}$ con máximo de $17.9 \mathrm{~m}$ en época de lluvias y mínimo de 14.6 $m$ en época seca. La temperatura superficial del agua presentó un promedio de $19.6^{\circ} \mathrm{C}$, el oxígeno disuelto de $10.2 \mathrm{mg} / \mathrm{l}$, el porcentaje de saturación de oxígeno de $119 \%$, la conductividad de $17.3 \mu \mathrm{S} / \mathrm{cm}$, los sólidos totales disueltos de $16.3 \mathrm{y}$ el $\mathrm{pH}$ de 7.5.

La quebrada El Cardal presenta sustrato de arenas-guijarros, con presencia de rocas de gran tamaño aguas arriba de los sitios de muestreo, en ambas riberas el uso local del suelo predominante es de pastos para ganadería en la zona cercana a la desembocadura en el río Guatapé y en el margen derecho de la quebrada hay un campamento habitacional de Empresas Públicas de Medellín que realiza vertimientos a la quebrada; y para las partes más altas predomina el bosque nativo en buen estado de conservación. Presentó una profundidad media entre $0.30-0.60 \mathrm{~m}$, aunque con algunas pozas de mayor profundidad. El ancho promedio fue de $11.1 \mathrm{~m}$ con máximo de $12.3 \mathrm{~m}$ en época de lluvias y mínimo de $9.1 \mathrm{~m}$ en época seca. La temperatura superficial del agua presentó un promedio de $20.8^{\circ} \mathrm{C}$, el oxígeno disuelto de 7.5 $\mathrm{mg} / \mathrm{l}$, el porcentaje de saturación de oxígeno de $76 \%$, la conductividad de $62.7 \mu \mathrm{S} / \mathrm{cm}$, los sólidos totales disueltos de 42.3 y el pH de 7.3

Características de los ejemplares y la dieta. Los individuos de $S$. dariensis analizados fueron peces con una longitud estándar media de $104.8 \mathrm{~mm}$ (Desviación estándar 19.3) con tallas entre $72.3 \mathrm{~mm}$ y $156.2 \mathrm{~mm}$. Por zonas de muestreo se observa una diferencia significativa en talla entre los ejemplares capturados en las dos quebradas $(p=0.000)$, para Peñoles la talla media de longitud estándar (LE) de los individuos estudiados fue de $119.8 \mathrm{~mm}$ (Desviación estándar 14.1, Mín. 90.3, Máx. 156.2) y para El Cardal de 92 mm (Desviación estándar 12.8, Mín. 72.3, Máx. 138.9). Por morfotipo bucal también se observa diferencia significativa $(p=0.000)$ en la longitud estándar entre los individuos con boca en media luna que son más grandes que los de boca recta en las dos quebradas, y por período climático se observó diferencia significativa $(p=0.001)$ durante el período seco en la quebrada El Cardal en el cual la talla media de LE fue de $101 \mathrm{~mm}$, mientras que para el período de transición fue de $87.6 \mathrm{~mm}$ y lluvias de $86.4 \mathrm{~mm}$ (Tabla 2 y 3 ). a barrier mainly during the dry season, when the flow of the stream is low. It has an average depth between 0.40-0.60 m, albeit with some deeper pools. The average width was $16.5 \mathrm{~m}$ with a maximum of $17.9 \mathrm{~m}$ in the rainy season and a minimum of $14.6 \mathrm{~m}$ in the dry season. The surface temperature of the water was on average at $19.6^{\circ} \mathrm{C}$, oxygen dissolved was $10.2 \mathrm{mg} / \mathrm{l}$, the oxygen saturation percentage $119 \%$, conductivity $17.3 \mu \mathrm{S} / \mathrm{cm}$, total solids dissolved 16.3 and the $\mathrm{pH} 7.5$.

The El Cardal stream has a sandy-pebbly substrate, with large rocks upstream the sampling sites, on both banks the land is predominantly used locally for livestock pastures in the area close to the mouth in the Guatape River and on the right bank of the stream there is a residential camp of Empresas Publicas de Medellin which carries out discharges into the stream; and the highest parts are dominated by a native forest in good state of conservation. It has an average depth between $0.30-0.60 \mathrm{~m}$, albeit with some deeper pools. The average width was $11.1 \mathrm{~m}$ with a maximum of $12.3 \mathrm{~m}$ in the rainy season and a minimum of $9.1 \mathrm{~m}$ in the dry season. The surface temperature of the water was on average at $20.8^{\circ} \mathrm{C}$, dissolved oxygen was $7.5 \mathrm{mg} / \mathrm{l}$, oxygen saturation percentage $76 \%$, conductivity $62.7 \mu \mathrm{S} / \mathrm{cm}$, total solids dissolved 42.3 and $\mathrm{pH} 7.3$

Characteristics of specimens and diet. The individuals of $S$. dariensis analyzed were fish with a standard average length of $104.8 \mathrm{~mm}$ (standard deviation of 19.3) with sizes between $72.3 \mathrm{~mm}$ and $156.2 \mathrm{~mm}$. In the sampling zones a significant difference in size between the specimens captured in the two streams $(p=0.000)$ is observed, for the Peñoles stream the mean standard length size (SL) of individuals studied was $119.8 \mathrm{~mm}$ (standard deviation of 14.1, Min 90.3, Max. 156.2) and $92 \mathrm{~mm}$ for El Cardal stream (standard deviation of 12.8, Min 72.3, Max. 138.9). A significant difference by oral morphotype is also observed $(p=0.000)$ in the standard length between individuals with a crescent-shaped mouth which are larger that those with a straight mouth in the two streams, and a significant difference was observed in the climate period $(p=0.001)$ during the dry season in the El Cardal stream in which the average SL size was 101 $\mathrm{mm}$, while for the transition period it was $87.6 \mathrm{~mm}$ and in the rainy season of $86.4 \mathrm{~mm}$ (Table 2 and 3).

The stomachs of $S$. dariensis show a saccular form, being longer (average of $18.0 \mathrm{~mm}$;) standard deviation of 4.6) than wider (average of $8.0 \mathrm{~mm}$; standard deviation of 2.4). The average intestine length was $86.5 \mathrm{~mm}$ (standard deviation of 24.8). From two to ten pyloric caeca were observed being 8 the most frequent number (average: 
Table 2. Average standard length value $(\mathrm{mm})$ for Saccodon dariensis by stream, climatic period and oral morphotype in the Guatape River mid-basin, East of Antioquia, Colombia.

\begin{tabular}{|c|c|c|c|c|}
\hline \multirow[b]{2}{*}{ Stream } & \multirow[b]{2}{*}{ Period } & \multicolumn{2}{|c|}{ Mouth shape } & \multirow[b]{2}{*}{ Total } \\
\hline & & $\begin{array}{c}\text { Straight } \\
\text { mouth }\end{array}$ & $\begin{array}{c}\text { Crescent- } \\
\text { shaped mouth }\end{array}$ & \\
\hline \multirow{4}{*}{ Peñoles } & Rain & 108.0 & 130.4 & 119.2 \\
\hline & Transition & 121.3 & 119.9 & 120.3 \\
\hline & Dry & 114.1 & 125.9 & 120.3 \\
\hline & Subtotal & $112.1 * *$ & $125.8^{* *}$ & 119.8* \\
\hline \multirow{4}{*}{ El Cardal } & Rain & 81.8 & 91.0 & 86.4 \\
\hline & Transition & 82.7 & 92.5 & 87.6 \\
\hline & Dry & 93.0 & 107.7 & $101.0 * * *$ \\
\hline & Subtotal & $85.8 * *$ & $97.7 * *$ & $92.0 *$ \\
\hline Total & & $97.2 * *$ & $111.3 * *$ & 104.8 \\
\hline
\end{tabular}

* Significant differences between streams; ** Significant differences between morphotypes; $* * *$ Significant differences between climatic periods.

Los estómagos de $S$. dariensis presentan forma sacular, siendo más largos (media 18.0 $\mathrm{mm}$; Desviación estándar 4.6) que anchos (media $8.0 \mathrm{~mm}$; Desviación estándar 2.4). La longitud media del intestino fue de $86.5 \mathrm{~mm}$ (Desviación estándar 24.8). Se observaron de dos a diez ciegos pilóricos siendo 8 el número más frecuente (media: 6.18, Desviación estándar 1.7). Se encontró una positiva y media correlación entre longitud estándar (LE) vs. longitud del intestino vs. (Longitud del intestino $\left.=0.9325^{*}(L E)-9.1881, r=0.76, n=112\right)$, longitud estándar (LE) vs. longitud del estómago (Longitud del estómago $=0.1665 *(\mathrm{LE})+0.6756$, $r=0.77, n=111)$, longitud estándar (LE) vs. ancho del estómago (Ancho del estómago $=0.0862 *(L E)-1.1573, r=0.75$, $\mathrm{n}=112)$; mientras que el peso total vs la longitud estándar presentó una alta correlación (Peso del $\left.p e z=0.00004 *(L E)^{3.334}, r=0.98, n=117\right)$.

Del total de 117 estómagos, sólo $2(1.7 \%)$ se encontraron vacíos. El contenido estomacal de los 115 estómagos se agrupó en 14 items alimenticios. De estos, el más importante lo constituyeron las algas con (V: $86.4 \%$; FO: 94.9\%; IIA: 91.9\%), seguido por Trichoptera (V: 3.4\%; FO: 39.3\%; IIA: 3.9\%), material vegetal (V: $4.8 \%$; FO: $15.4 \%$; IIA: $1.8 \%$ ), y restos de insectos (V: 2.5\%; FO: 12.8\%; IIA: $0.4 \%$ ) (Tabla 4).

Para las algas se registraron 74 géneros de cinco divisiones: 29 géneros de Chlorophyta, 25 de Bacillariophyta, 16 de Cianophyta, 2 de Bacteriophyta y 2 de Euglenophyta. En el análisis volumétrico las divisiones más importantes fueron Bacillariophyta (94.1\%), Cianophyta (3.8\%) y Chlorophyta (2.1\%). Así, los géneros más importantes Fragilaria (V: 71.0\%; FO:
Table 3. ANOVA to contrast size differences of Saccodon dariensis by stream, climatic period and oral morphotype in the Guatape River mid-basin, East of Antioquia, Colombia.

\begin{tabular}{lccccc}
\hline $\begin{array}{c}\text { Sources of } \\
\text { variation }\end{array}$ & $\begin{array}{c}\text { Sum of } \\
\text { squares }\end{array}$ & gl & $\begin{array}{c}\text { Mean } \\
\text { square }\end{array}$ & F & P \\
\hline (A) Stream & 20070.200 & 1 & 20070.200 & 172.950 & $\mathbf{0 . 0 0 0}$ \\
(B) Climatic period & 1705.830 & 2 & 852.915 & 7.350 & $\mathbf{0 . 0 0 1}$ \\
(C) Oral morphotype & 4819.380 & 1 & 4819.380 & 41.530 & $\mathbf{0 . 0 0 0}$ \\
(D) Sex & 12.199 & 1 & 12.199 & 0.110 & 0.746 \\
A x B interaction & 1002.970 & 2 & 501.486 & 4.320 & $\mathbf{0 . 0 1 6}$ \\
Remainder & 12648.700 & 109 & 116.043 & & \\
\hline Total & 40259.279 & 116 & & & \\
\hline
\end{tabular}

Bold values denote statistical significance.

6.18 , standard deviation of 1.7). A positive and average correlation was observed between the standard length (SL) vs. the intestine length vs. (intestine length $=0.9325^{*}(\mathrm{SL})-9.1881, r=0.76$, $n=112$ ), standard length (SL) vs. stomach length (stomach length $=0.1665^{*}(\mathrm{SL})+0.6756, r=0.77$, $\mathrm{n}=111$ ), standard length ( $\mathrm{SL})$ vs. stomach width (stomach width $=0.0862 *(\mathrm{SL})-1.1573$, $r=0.75, n=112)$; while the weight total vs. standard length showed a high correlation (fish weight $\left.=0.00004 *(L E)^{3.334}, r=0.98, n=117\right)$.

Of the total of 117 stomachs, only $2(1.7 \%)$ were found empty. The stomach contents of the 115 stomachs were grouped into 14 food items. Of these, the most important was algae (V: $86.4 \%$; FO: $94.9 \%$; FII: $91.9 \%$ ), followed by Trichoptera (V: $3.4 \%$; FO: 39.3\%; FII: 3.9\%), vegetal material (V: 4.8\%; FO: 15.4\%; FII: $1.8 \%$ ) and insects remains (V: 2.5\%; FO: $12.8 \%$; FII: $0.4 \%$ ) (Table 4 ).

Seventy-four genera with five divisions were recorded for algae: 29 genera of Chlorophyta, 25 of Bacillariophyta, 16 of Cianophyta, 2 of Bacteriophyta and 2 of Euglenophyta. In the volumetric analysis the most important divisions were Bacillariophyta $(94.1 \%)$, Cianophyta $(3.8 \%)$ and Chlorophyta (2.1\%). Thus, the most important genera were Fragilaria (V: 71.0\%; FO: $95.4 \%$ ), Stauroneis (V: 10.4\%; FO: $67.0 \%$ ), Gomphonema (V: 6.5\%; FO: $88.1 \%$ ), Cymbella (V: 1.9\%; FO: 95.4\%), Gloeotrichia (V: 1.4\%; FO: $22.0 \%$ ) and Pseudolyngbya (V: $1.3 \%$; FO: $30.2 \%$ ) (Table 5).

The principal components analysis (PCA) does not show any differences in feed between streams, climatic periods, oral polymorphism, sex or developmental state. The most important 
Table 4. Food categories found in the stomach contents of Saccodon dariensis in the Guatape River midbasin, Colombia.

\begin{tabular}{lccc}
\hline & Volume \% V (\%) & Frequency \% F (\%) & Food importance index (\%) \\
\hline Algae & 86.359 & 94.872 & 91.926 \\
Vegetal material & 4.774 & 15.385 & 1.786 \\
Trichoptera & 3.450 & 39.316 & 3.868 \\
Insect remains & 2.549 & 12.821 & 0.350 \\
Ephemeroptera & 0.005 & 2.564 & 0.000 \\
Hemiptera & 0.006 & 1.709 & 0.001 \\
Diptera & 0.107 & 13.675 & 0.023 \\
Coleoptera & 0.116 & 7.692 & 0.038 \\
Lepidoptera & 0.041 & 1.709 & 0.011 \\
Odonata & 0.006 & 0.855 & 0.001 \\
Acari & 0.012 & 6.838 & 0.003 \\
Eggs & 0.055 & 8.547 & 0.009 \\
Scales & 0.011 & 1.709 & 0.001 \\
Digested material & 2.508 & 32.479 & 1.983 \\
\hline
\end{tabular}

95.4\%), Stauroneis (V: 10.4\%; FO: 67.0\%), Gomphonema (V: 6.5\%; FO: 88.1\%), Cymbella (V: 1.9\%; FO: 95.4\%), Gloeotrichia (V: 1.4\%; FO: $22.0 \%$ ) y Pseudolyngbya (V: $1.3 \%$; FO: $30.2 \%$ ) (Tabla 5).

El análisis de componentes principales (ACP) no indica diferencias en la alimentación entre quebradas, períodos climáticos, polimorfismo bucal sexos o estado de desarrollo. El ítem alimenticio más importante para las dos quebradas lo constituyeron las algas con un IIA de $92.19 \%$ y $91.70 \%$, seguido de insectos y restos de insectos con IIA de $5.57 \%$ y $3.20 \%$, para las quebradas Peñoles y El Cardal respectivamente. Por períodos climáticos, existe un aumento en el consumo de material vegetal en el período seco $(2.26 \%)$ y en transición $(3.30 \%)$ con relación al período de lluvias $(0.16 \%)$, y en el consumo de insectos en especial del Orden Trichoptera mayor en los períodos de lluvia y seco (Tabla 6).

El índice de importancia alimentaria (IIA) muestra para los individuos con la boca en media luna que el mayor ítem alimenticio en su dieta son las algas $(96.1 \%)$ y un consumo bajo de Insectos y restos de insectos $(0.49 \%)$, y material vegetal $(0.11 \%)$. Por su parte, los individuos con boca recta presentan una reducción en el consumo de algas, aunque sigue siendo el mayor ítem alimenticio en su dieta con un $87.10 \%$, pero es mayor el consumo de Insectos y restos de insectos con un $8.74 \%$ y material vegetal con $3.75 \%$. El análisis de varianza (ANOVA) para identificar las diferencias entre las dietas indicó diferencias significativas $(p=0.038)$ únicamente por morfotipo bucal para el
Table 5. Volume and occurrence of algae in the stomach contents of Saccodon dariensis in the Guatape River mid-basin, Colombia.

\begin{tabular}{|c|c|c|c|c|c|}
\hline & $\% \mathrm{~V}$ & $\%$ FO & & $\% \mathrm{~V}$ & $\% F O$ \\
\hline \multicolumn{6}{|l|}{ Bacillariophyta } \\
\hline Achnanthes sp. & 0.001 & 2.752 & Nostoc & 0.037 & 2.752 \\
\hline Nitzschia & 0.243 & 55.046 & Oscillatoria & 0.640 & 59.633 \\
\hline Aulacoseira & 0.007 & 1.835 & Plectonema & 0.000 & 0.917 \\
\hline Heterothrix & 0.003 & 1.835 & Pleurocapsa & 0.097 & 8.257 \\
\hline Amphora & 0.003 & 2.752 & Rivularia & 0.165 & 13.761 \\
\hline Asterionella & 0.000 & 0.917 & Stigonema & 0.131 & 15.596 \\
\hline Ceratoneis & 0.070 & 14.679 & Euglenophyta & & \\
\hline Cyclotella & 0.071 & 15.596 & Facus & 0.006 & 1.835 \\
\hline Cocconeis & 0.334 & 59.633 & Euglena & 0.000 & 0.917 \\
\hline Cymatopleura & 0.008 & 0.917 & Chlorophyta & & \\
\hline Cymbella & 1.893 & 95.413 & Ankistrodesmus & 0.012 & 8.257 \\
\hline Diatoma & 0.019 & 12.844 & Bostrychia & 0.001 & 1.835 \\
\hline Fragilaria & 71.007 & 98.165 & Pseudolyngbya & 1.269 & 30.275 \\
\hline Gomphonema & 6.518 & 88.073 & Leptolyngbya & 0.011 & 2.752 \\
\hline Hantzschia & 0.026 & 6.422 & Spirotaenia & 0.003 & 1.835 \\
\hline Melosira & 1.789 & 76.197 & Bulbochaete & 0.027 & 2.752 \\
\hline Navicula & 0.850 & 77.981 & Schizomeris & 0.002 & 0.917 \\
\hline Rhoicosphenia & 0.152 & 14.679 & Crenothrix & 0.007 & 2.752 \\
\hline Stauroneis & 10.375 & 66.972 & Chaetophora & 0.031 & 10.092 \\
\hline Surirella & 0.564 & 73.394 & Chlorhormidium & 0.025 & 2.752 \\
\hline Synedra & 0.002 & 0.917 & Cladophora & 0.067 & 19.266 \\
\hline Tabellaria & 0.095 & 25.688 & Coleochaete & 0.001 & 1.835 \\
\hline Eutonia & 0.005 & 2.752 & Crucigenia & 0.004 & 1.835 \\
\hline Pinnularia & 0.027 & 3.670 & Geminella & 0.016 & 0.917 \\
\hline Gyrosigma & 0.002 & 0.917 & Gloeocystis & 0.007 & 2.752 \\
\hline Bacteriophyta & & & Microspora & 0.000 & 0.917 \\
\hline Chlorotylium & 0.006 & 2.752 & Oedogonium & 0.256 & \\
\hline Sphaerotilus & 0.001 & 0.917 & Pleurococcus & 0.000 & \\
\hline Cianophyta & & & Scenedesmus & 0.001 & 0.917 \\
\hline Anabaena & 0.185 & 5.505 & Sphaeroplea & 0.004 & 1.835 \\
\hline Aphanizomenon & 0.004 & 1.835 & Ulothrix & 0.176 & 14.679 \\
\hline Calothrix & 0.202 & 22.936 & Penium & 0.001 & 2.752 \\
\hline Chamaesiphon & 0.003 & 0.917 & Closterium & 0.030 & 14.679 \\
\hline Pseudoanabaena & 0.019 & & Cosmarium & 0.015 & 6.422 \\
\hline Chroococcus & 0.001 & 1.835 & Gonatozygon & 0.000 & \\
\hline Gloeotrichia & 1.407 & 22.018 & Pleurotaenium & 0.004 & 0.917 \\
\hline Microcystis & 0.001 & 0.917 & Tetmemorus & 0.003 & 0.917 \\
\hline Lyngbya & 0.930 & 48.624 & Mougeotia & 0.116 & 23.853 \\
\hline Merismopedia & 0.000 & 0.917 & Spirogyra & 0.006 & 3.670 \\
\hline
\end{tabular}


Table 6. Food Importance Index (\%) for the food items of Saccodon dariensis by stream and climatic period in the Guatape River mid-basin, Colombia.

\begin{tabular}{lccccc}
\hline & \multicolumn{2}{c}{ Stream } & \multicolumn{3}{c}{ Climatic period } \\
\cline { 2 - 6 } & Peñoles & El cardal & Lluvia & Seco & Transición \\
\hline Algae & 92.19 & 91.70 & 92.64 & 89.65 & 93.89 \\
$\begin{array}{l}\text { Vegetal } \\
\text { material }\end{array}$ & 1.01 & 0.25 & 0.16 & 2.26 & 3.30 \\
$\begin{array}{l}\text { Insects and } \\
\text { insect remains }\end{array}$ & 5.57 & 3.20 & 5.15 & 5.37 & 1.78 \\
$\begin{array}{l}\text { Digested } \\
\text { material }\end{array}$ & 1.23 & 2.63 & 2.03 & 2.68 & 1.02 \\
\hline
\end{tabular}

Table 7. Food Importance Index (FII) for juveniles and adults of Saccodon dariensis for each oral morphotype.

\begin{tabular}{lcccccc}
\hline & \multicolumn{3}{c}{ Straight mouth } & \multicolumn{3}{c}{ Crescent-shaped mouth } \\
\cline { 2 - 7 } & Juveniles & Adultos & Total & Juveniles & Adultos & Total \\
\hline Algae & 91.02 & 73.51 & 87.06 & 95.53 & 96.52 & 96.09 \\
$\begin{array}{l}\text { Insects } \\
\text { and insect } \\
\text { remains }\end{array}$ & $4.82^{*}$ & $22.15^{*}$ & 8.74 & $0.08^{*}$ & $0.81^{*}$ & 0.49 \\
$\begin{array}{l}\text { Vegetal } \\
\text { material }\end{array}$ & 3.73 & 3.83 & $3.75^{* *}$ & 0.00 & 0.18 & $0.11^{* *}$ \\
\hline
\end{tabular}

Mann-Whitney pairwise comparison test. *Significant differences between juveniles and adults in each morphotype **Significant differences between oral morphotypes.

consumo de material vegetal, el cual es mayor en individuos de boca recta y la comparación puntual entre ítems alimenticios con la prueba de comparación por pares de Mann-Whitney indica diferencias significativas por morfotipo bucal en el consumo de material vegetal siendo mayor en los individuos con boca recta $(p=0.034)$ (Tabla 7).

Dentro de los dos morfotipos se encontró un aumento significativo en el consumo de insectos al pasar de juveniles a adultos (boca recta: $p=0.034$, boca en media luna: $p=0.000$ ), siendo éste más alto para individuos de boca recta donde pasan de $4.82 \%$ a representar un $22.15 \%$ del IIA (Tabla 7).

Se observó variación en el volumen consumido de los diferentes géneros de algas entre los individuos con diferente tipo de boca. Para ejemplares con boca recta los géneros más importantes son Fragilaria (\%V: 80.6) y Stauroneis (\%V: 11.8 ); mientras que para los de boca en media luna hay importancia en el consumo de una mayor variedad de géneros, siendo Gomphonema el más importante con (\%V: 33.6), seguido de Fragilaria (\%V: 16.1), Cymbella (\%V: 8.9), Melosira (\%V: 8.5), Lingbya (\%V: 5.9), entre otros (Tabla 8 ). food item in the two streams was algae with an FII of $92.19 \%$ and $91.70 \%$, followed by insects and insect remains with an FII of $5.57 \%$ and $3.20 \%$ for the Peñoles and El Cardal streams, respectively. By climatic periods, there is an increase in the consumption of vegetation material in the dry period (2.26\%) and in the transition period $(3.30 \%)$ in relation to the rainy period $(0.16 \%)$, and in the consumption of insects, especially of the order Trichoptera, which is greater in rainy and dry periods (Table 6 ).

The food importance index (FII) shows for individuals with a crescent-shaped mouth that the main food item in their diet is algae (96.1\%) and a low consumption of insects and insect remains $(0.49 \%)$, and vegetation material $(0.11 \%)$. Moreover, individuals with a straight mouth showed a reduction in the consumption of algae, although it remains the main food item in their diet with $87.10 \%$, but the consumption of insects and insect remains is higher at $8.74 \%$ and vegetation material with $3.75 \%$. The analysis of variance (ANOVA) to identify differences between diets showed significant differences $(p=0.038)$ only by oral morphotype for the consumption of vegetation material, which is higher in individuals with a straight mouth and the specific comparison between food items with the MannWhitney pairwise comparison test indicates significant differences by oral morphotype for the consumption of vegetation material being higher in individuals with a straight mouth $(p=0.034)$ (Table 7).

A significant increase in the consumption of insects was found within the two morphs when passing from youth to adults (straight mouth: $p=0.034$, crescent-shaped mouth: $p=0.000)$, being this the highest for individuals with a straight mouth as they went from $4.82 \%$ to $22.15 \%$ of the FII (Table 7 ).

A variation was observed in the volume consumed of the different genera of algae between individuals with a different type of mouth. For specimens with a straight mouth, the most important genera are Fragilaria (V\%: 80.6) and Stauroneis (V\%: 11.8); while for those with a crescent-shaped mouth there is an importance in the consumption of a greater variety of genres, being Gomphonema the most important with (V\%: 33.6), followed by Fragilaria (V\%: 16.1), Cymbella (V\%: 8.9), Melosira (V\% 8.5), Lingbya (V\% 5.9), among others (Table 8). 
Table 8. Volume percentage (V\%) of algae in the stomach contents of Saccodon dariensis for each oral morphotype, in the Guatape River mid-basin, Colombia.

\begin{tabular}{lcr}
\hline & Genus & Crescent-shaped mouth \\
\hline Fragilaria & Straight mouth & 16.05 \\
Stauroneis & 80.59 & 2.22 \\
Gomphonema & 11.80 & 33.61 \\
Gloeotrichia & 1.80 & 1.46 \\
Pseudolynbbya & 1.40 & 1.13 \\
Cymbella & 1.29 & 8.95 \\
Melosira & 0.66 & 8.47 \\
Navicula & 0.63 & 3.55 \\
Oscillatoria & 0.38 & 2.22 \\
Cocconeis & 0.36 & 1.44 \\
Surirella & 0.14 & 3.10 \\
Lyngbya & 0.12 & 5.87 \\
Calothrix & 0.07 & 0.98 \\
Anabaena & 0.07 & 1.20 \\
\hline
\end{tabular}

\section{DISCUSIóN}

Saccodon dariensis presentó mayor talla media en la quebrada Peñoles (119.8mm LE) con relación a los individuos capturados en la quebrada El Cardal (92mm LE), lo que puede estar relacionado con el hecho de que la quebrada Peñoles presenta un mayor ancho y profundidad. Esto coincide con lo descrito por Restrepo-Escobar (29), para especímenes de sabaleta Brycon henni de las cuencas medias de los ríos Nare y Guatapé (Colombia), donde se encontró diferencia significativa en tamaño, siendo los individuos de mayor tamaño capturados en los ríos y quebradas de mayor caudal medio y profundidad de la columna de agua. El alto porcentaje de individuos que están por debajo de la talla media de madurez sexual (17) en la quebrada El Cardal, permite inferir que es un área de importancia para el crecimiento y desarrollo. La comparación de medias de la longitud estándar entre los tipos de boca mostró que los individuos con boca en media luna presentaron un tamaño promedio mayor que los de boca recta en las dos quebradas, lo cual ha sido descrito para la especie por Restrepo-Escobar (29), quien sugiere respuestas diferenciales de los morfotipos a los factores que influyen en la talla que podrían estar determinados genéticamente 0 reflejar plasticidad fenotípica.

Saccodon dariensis se alimenta casi exclusivamente de algas, principalmente de la división Bacillariophyta o diatomeas que representan las densidades más altas $(\% \mathrm{~V}=94.1)$ y es el ítem más frecuente e importante en todos los contenidos estudiados tanto en estadios juveniles como adultos. Las diatomeas pertenecientes a la familia naviculaceae están adaptadas a corrientes que presenten altos caudales o sistemas con alta incidencia de arrastre de sedimentos o influenciados por importantes escorrentías, además están

\section{DISCUSSION}

Saccodon dariensis showed a higher mean size in the Peñoles stream (SL $119.8 \mathrm{~mm}$ ) in relation to individuals captured in the El Cardal stream (SL $92 \mathrm{~mm}$ ), which may be related to the fact that the Peñoles stream is wider and deeper. This is consistent with what has been described by Restrepo-Escobar (29), for specimens of Brycon henni in the middle basins of the Nare and Guatape rivers (Colombia), where a significant differences in size was found, with the largest individuals being caught in rivers and streams with a higher average flow and water column depth. The high percentage of individuals below the mean size at sexual maturity (17) in the El Cardal stream, allows us to infer that it is an important area for growth and development. The comparison of the average standard length between mouth types showed that individuals with a crescent-shaped mouth had a larger average size than those with a straight mouth in the two streams, which has been described for the species by Restrepo-Escobar (29), suggesting responses for morphotypes different to the factors influencing the size that could be determined genetically or reflect a phenotypic plasticity.

Saccodon dariensis feeds almost exclusively on algae, mainly Bacillariophyta or diatoms that represent the highest densities $(\mathrm{V} \%=94.1)$ and is the most frequent and important item in all contents studied both in juvenile stages as in adults. Diatoms belonging to the family naviculaceae have adapted to streams with high flow rates or systems with a high incidence of sediment entrainment or that have been influenced by significant runoffs, which also usually consist of certain substances with a 
generalmente constituidos por ciertas sustancias de alto valor energético por lo cual constituyen una importante oferta para macroinvertebrados o peces que se alimentan de algas perifíticas (25).

De otra parte, se encontró un aumento significativo en el consumo de insectos al pasar de juveniles a adultos, principalmente en individuos de boca recta donde pasan de $4.8 \%$ a representar más de un $22 \%$ del IIA, se destaca el consumo de insectos Trichoptera y dentro de este, de Helycopsichidae, que poseen mandíbulas raspadoras para obtener el perifiton y las partículas finas que recubren la superficie de las rocas. La baja proporción de categorías de insectos en la dieta y su menor frecuencia de ocurrencia permiten inferir que la ingestión de material animal es, probablemente muy ocasional. Al respecto, Zamudio et al (9) y Mojica-Corzo et al (10) destacan para $S$ dariensis el consumo de insectos acuáticos de los órdenes Diptera, Trichoptera, Ephemeroptera y Plecoptera que se adhieren a la superficie de las rocas, los cuales capturan con ayuda de sus dientes superiores. Igualmente, otros autores (4,7-10), han encontrado que las especies de Parodontidae consumen preferencialmente algas e insectos acuáticos. Parodon caliensis en ocasiones consume accidentalmente perifiton y material inorgánico, pero muestra mayor preferencia por insectos acuáticos (Ephemeroptera, Trichoptera, Plecoptera y Diptera) y terrestres (Hymenoptera familia Formicidae y Coleoptera), Parodon buckleyi en el piedemonte de la Orinoquia Colombiana se alimenta principalmente de algas y $P$. suborbitalis en el alto Cauca se alimentan de algas y materia orgánica que raspan de las rocas e insectos acuáticos que permanecen entre la grava (13).

En conclusión Saccodon dariensis es una especie principalmente alguívora con ocasional consumo de insectos y material vegetal y en la comparación de dieta por zonas y período climático no se hallaron diferencias. Los morfotipos bucales en $S$. dariensis pueden estar relacionadas con un polimorfismo trófico dadas las diferencias significativas con un mayor consumo de material vegetal en los individuos de boca recta $(p=0.034)$, al igual que proporciones diferentes en el consumo de diferentes géneros de algas entre los dos morfotipos (para los individuos de boca recta los géneros más importantes fueron Fragilaria y Stauroneis, mientras que para los de boca en media luna hay una mayor importancia en el consumo de más variedad de géneros, siendo Gomphonema el más importante), y el aumento de consumo de insectos al pasar de juveniles a adultos, siendo éste más alto para individuos de boca recta. Es posible, que estas diferencias en la dieta se justifiquen por el tipo de boca y la forma de los dientes descritas por Roberts (5) para los dos morfotipos, high energetic value, therefore constituting an important offer for macroinvertebrates and fish that feed on periphytic algae (25).

On the other hand, a significant increase in the consumption of insects was found when going from youth to adults, mainly individuals with a straight mouth where they pass from $4.8 \%$ to representing more than $22 \%$ of the FII, the consumption of Trichoptera insects stands out and within this, Helycopsichidae, which possess scraping jaws to obtain periphyton and fine particles that cover the surface of rocks. The low proportion of insect categories in the diet and their lower frequency of occurrence allow inferring that the ingestion of animal material is probably very seldom. In this regard, Zamudio et al (9) and Mojica-Corzo et al (10) indicate the consumption for $S$ dariensis of aquatic insects of the orders Diptera, Trichoptera, Ephemeroptera, and Plecoptera that adhere to the surface of the rocks, which are caught with the help of their upper teeth. Likewise, other authors $(4,7-10)$ have found that the species of Parodontidae preferentially consume algae and aquatic insects. Parodon caliensis accidentally consumes periphyton and inorganic material, but shows a greater preference for aquatic insects (Ephemeroptera, Trichoptera, Plecoptera and Diptera) and terrestrial insects (Hymenoptera family Formicidae and Coleoptera), Parodon buckleyi in the foothills of the Colombian Orinoquia feeds mainly on algae and $P$. suborbitalis in the upper Cauca feed on algae and organic matter scraped from rocks and aquatic insects that lie in the gravel (13).

In conclusion Saccodon dariensis is a mainly algaevorous species with occasional consumption of insects and vegetation material and no differences were found in the comparison of diet by areas and climate period. The oral morphotypes of $S$. dariensis may be related to a trophic polymorphism given the significant differences with the increased consumption of vegetation material in individuals with a straight mouth ( $p=0.034)$, as well as different proportions in the consumption of different genera of algae between the two morphotypes (for individuals with an straight mouth the most important genera were Fragilaria and Stauroneis, while for those with a crescent-shaped mouth there is a greater importance in the consumption of a greater variety of genres, with Gomphonema being the most important), and the increase in the consumption of insects when going from youth to adults, being this higher for individuals with a straight mouth. It is possible that these differences in diet are justified by the type of mouth and the shape of the teeth described by Roberts (5) for 
que les confiere diferencias para el acceso a los recursos de alimento, al permitir a los peces de boca recta con dientes con cúspides acceder al recurso ramoneando las algas filamentosas que mordisquean por encima del sustrato, al ingerir en este proceso de forma ocasional insectos y otro material vegetal, mientras que los de boca en media luna lo hacen como raspadores, al obtener algas muy cerca del sustrato haciendo uso de sus dientes lisos en forma de cuchara.

Estas formas de obtener algas bentónicas actuando como ramoneadores o como raspadores también han sido descritas para Parodon tortuosus (7). Finalmente, los cambios en estos componentes de la dieta pueden estar asociados con las diferencias en el tamaño de ejemplares entre morfotipos, teniendo diferentes influencias a nivel nutricional, pero esto debe ser explorado por estudios de dieta a partir de isótopos estables (30).

\section{Agradecimientos}

A la Corporación Autónoma Regional de los Ríos Negro y Nare (CORNARE), a ISAGEN S.A. E.S.P. y a la Universidad Nacional de Colombia, quienes financiaron el proyecto 20101009235: "Estudio de la biología, ecología y diversidad genética de las poblaciones naturales de sabaleta Brycon henni en las cuencas de los ríos Nare y Guatapé, departamento de Antioquia", dentro del cual fue colectado el material biológico analizado en este estudio. A la Dirección de Investigación Medellín -DIME y a la Vicedecanatura de Investigación de la Facultad de Ciencias Agrarias de la Universidad Nacional de Colombia. Al Profesor Alvaro Lema por el apoyo en el análisis estadístico y a los revisores anónimos por sus acertados comentarios. the two morphotypes, which provides differences for access to food resources, as the fish with a straight mouth with cusped teeth are able to access the resource by foraging filamentous algae nibbled above the substrate, occasionally ingesting in this process insects and other vegetal material, while fish with a crescent-shaped mouth make it by scrapping, as they obtain algae close to the substrate using their spoon-shaped smooth teeth.

These forms for obtaining benthic algae acting as foragers or scrapers have also been described for Parodon tortuosus (7). Finally, changes in these diet components may be associated with differences in the size of specimens between morphotypes, having different nutritional influences, but this must be explored through diet studies from stable isotopes (30).

\section{Acknowledgements}

The Autonomous Regional Corporation of the Negro and Nare rivers (CORNARE), ISAGEN S.A. E.S.P. and Universidad Nacional de Colombia, which funded the project 20101009235: "Study of the biology, ecology and genetic diversity of natural populations of Brycon henni in the basins of the Nare and Guatape rivers, department of Antioquia," where the biological material analyzed in this study was collected. To the Medellin Research Department - DIME and the Dean's Office for Research of the Faculty of Agricultural Sciences of Universidad Nacional de Colombia. Professor Alvaro Lema for his support with statistical analysis and the anonymous reviewers for their commentaries.

\section{REFERENCES}

1. Jaramillo-Villa U, Maldonado-Ocampo JA, Escobar F. Altitudinal variation in fish assemblage diversity in streams of the central Andes of Colombia. J Fish Biol 2010; 76:2401-2417.

2. Anderson E, Maldonado-Ocampo JA. A Regional Perspective on the Diversity and Conservation of Tropical Andean Fishes. Conserv Biol 2011; 25(1):30-39.

3. Londoño-Burbano A, Román-Valencia $C$. Redescripción de Parodon caliensis y Saccodon dariensis (Characiformes: Parodontidae). Rev Biol Trop 2010; 58(3):813-826.

4. Reis RE, Kullander SO, Ferraris CJ (eds.) Checklist of the Freshwater Fishes of South and Central America. Porto Alegre Brasil: EDIPUCRS; 2003.
5. Roberts T. Dental polymorphism and systematics in Saccodon, a neotropical genus of freshwater fishes (Parodontidae, Characoidei). J Zool Lond $1974 ; 173: 303-321$.

6. Melo CE, Machado FA, Pinto-Silva V. Feeding habits of fish from a stream in the savanna of Central Brazil, Araguaia Basin. Neotrop Ichthyol 2004; 2(1):37-44.

7. Pelegrin N, Haro JG. Ecología alimentaria de Parodon tortuosus (Pisces, Characiformes) en el Río de La Suela, Córdoba (Argentina). Ecol Austral 2004; 14(1):45-51.

8. Rodríguez-Olarte D, Coronel JA, Taphorn D. Línea base para la estimación de la integridad en comunidades de peces en la cuenca del río Tocuyo, vertiente del Caribe, Venezuela. Mem Fund La Salle de Cienc Nat 2007; 165:63-81. 
9. Zamudio J, Urbano-Bonilla A, MaldonadoOcampo JA, Bogotá-Gregory JD, Cortés-Millán GA. Hábitos alimentarios de diez especies de peces del piedemonte del departamento del Casanare, Colombia. Dahlia Rev Asoc Colomb Ictiol 2008; 10:43-56.

10. Mojica-Corzo JI, Usma-Oviedo JS, Álvarez-León $\mathrm{R}$ \& Lasso-Alcalá CA (eds.). Libro rojo de peces dulceacuícolas de Colombia. Bogotá D.C.: Instituto de Investigación de Recursos Biológicos Alexander von Humboldt; 2012.

11. Pouilly M, Barrera S, Rosales C. Changes of taxonomic and trophic structure of fish assemblages along an environmental gradient in the upper Beni Watershed (Bolivia). J Fish Biol 2006; 68:137-156.

12. Maldonado-Ocampo JA, Vari RP, Usma JS. Checklist of the Freshwater Fishes of Colombia. Biota Col 2008; 9(2):143-237.

13. Ortega-Lara A, Aguiño A, Sánchez GC. Los peces del Alto Cauca: Caracterización de la ictiofauna nativa de los principales ríos de la cuenca alta del río Cauca en el departamento del Cauca. Popayán, Colombia: Fundación para la investigación y el Desarrollo Sostenible, FUNINDES y Corporación Autónoma Regional del Cauca CRC; 2002.

14. Amaya JD, Naranjo LG. Plan Nacional de las Especies Migratorias: Diagnóstico e identificación de acciones para la conservación y el manejo sostenible de las especies migratorias de la biodiversidad en Colombia. Bogotá, Colombia: MAVDT - WWF; 2009.

15. Villa-Navarro F, Briñez-Vásquez AN, Castro-Roa D, García-Melo LJ, García-Melo JE, HerradaYara ME. Biodiversidad faunística y florística de las cuencas de los ríos Prado y Amoyá Biodiversidad Regional Vol. II. Ibagué, Colombia: Cortolima y Universidad del Tolima; 2005.

16. Jaramillo-Villa U, Maldonado-Ocampo JA, Bogotá-Gregory JD. Peces del Oriente de Antioquia, Colombia. Biota Col 2008; 9(2):279-293.

17. Urrego-Ballestas DA, Castellanos-Barliza JJ, Mancera-Rodríguez NJ. Biología reproductiva de Saccodon dariensis (Pisces: Parodontidae) en la cuenca media del río Guatapé, Antioquia - Colombia. En: III Congreso Colombiano de Zoología; Medellín, Colombia,

18. Olsson J, Eklöv P. Habitat structure, feeding mode and morphological reversibility: factors influencing phenotypic plasticity in perch. Evol Ecol Res 2005; 7:1109-1123.
19. Rodríguez N, Armenteras D, Morales M, Romero M. Ecosistemas de los Andes colombianos. Bogotá, D.C.: Instituto de investigación de recursos Biológicos Alexander von Humboldt; 2004.

20. Wentworth C. A scale of grade and class terms for clastic sediments. J. Geology 1922; 30:377-392.

21. Ricker WE. Methods for assessment of fish production in fresh waters. $2^{a}$ ed..- 2 nd ed. Oxford: I.B.P. Handbook No 3. Blackwell Sci Publ; 1971.

22. Hyslop EJ. Stomach contents analysis a review of methods and their applications. J Fish Biol $1980 ; 17: 411-429$.

23. Kawakami E \& Vazzoler G. Método gráfico e estimativa de alimentar aplicado no estudo de alimentação de peixis. Bol Inst Oceanogr 1980; 29(2):205-207.

24. Bicudo $C E$, Menezes $M$. Géneros de algas de aguas continentales do Brasil. Sao Carlos, Brasil: Editorial Rima; 2006.

25. Ramírez JJ. Fitoplancton de agua dulce: aspectos ecológicos, taxonómicos y sanitarios. Medellín Colombia: Editorial Universidad de Antioquia; 2000.

26. Krammer K, Lange-Bertalot $\mathrm{H}$. Bacillariophyceae. Tomos 1,2,3,4. Berlin, Alemania: Verlag; 1949.

27. Streble H, Krauter D. Atlas de los microorganismos de Agua dulce. Barcelona, España: Editorial Omega S.A.; 1987.

28. Roldán-Pérez G. Guía para el estudio de los macro invertebrados acuáticos del departamento de Antioquia. Bogotá, Colombia: Fondo FEN Colombia, Colciencias y Universidad de Antioquia; 1996.

29. Restrepo-Escobar N. Brycon henni y Saccodon dariensis (Pisces: Characiformes): Análisis de la variación del cuerpo mediante el uso de la Morfometría geométrica. [Tesis de M.Sc.]. Medellín, Colombia: Universidad Nacional de Colombia, Facultad de Ciencias, Escuela de Biociencias; 2013.

30. Adams CE, Fraser D, McCarthy I, Shields S, Waldron S, Alexander G. Stable isotope analysis reveals ecological segregation in a bimodal size polymorphism in Arctic charr from LochTay, Scotland. J Fish Biol 2003; 62:474-481. 